\title{
The Commodification of Care: a Critical Exploration of the Marketing Mix for Domiciliary Care at the End-of-Life
}

\author{
Dr. Luciana Lolich \\ School of Social Policy, Social Work and Social Justice, UCD \\ Dublin, Ireland
}

(C) Luciana Lolich. This work is licensed under the Creative Commons Attribution-Noncommercial-Share Alike 4.0 International License. To view a copy of this license, visit https://creativecommons.org/licenses/by-nc-sa/4.0/ .

\section{Abstract}

The home care industry has grown exponentially around the world. In palliative care, the delivery of home care has been promoted as the ideal type of formal care; offering cost savings to local authorities and 'choice' for patients and their families. However, there is a dark side to the commodification of care that is rarely discussed in the marketing literature. The pursuit of profits, contracting and bureaucratising care can reduce care to physical, measurable elements and might ignore the emotional and relational aspects of care which cannot easily be costed or detailed in contracts. This paper critically examines the elements of the marketing mix for 'care packages' and highlights the impact of commodification on two parties involved in the market exchange: vulnerable patients and workers.

Keywords: Ireland; Domiciliary care; Marketing mix; Consumer choice; Affective equality

\section{Introduction}

The home care industry has grown exponentially around the world. Its value is expected to reach USD 349.8 billion by 2020 , growing at a compound annual growth rate (CAGR) of 9.0\% from 2015 to 2020 (Markets and Markets, 2015). The home care market is a highly attractive one (in profit terms) worldwide due to a range of factors including a rising aging population, increasing incidences of chronic diseases, technological advancements, and government initiatives to promote domiciliary healthcare (Eurostat, 2017; Tarricone and Tsouros, 2008). The home care service sector forms the largest part of the healthcare market (which also includes products, software and telehealth) due to their increasing demand and affordability (Markets and Markets 2015). Geographically, the home healthcare market is segmented into North America, Europe, Asia and the Rest of the World. In Ireland, the home care market was valued at $€ 340.27 \mathrm{M}$ in 2009 (PA Consulting and IPHCA, 2009).

Ireland's economic crisis in 2008 had an important impact on the Irish welfare state which to date has been predominately debated in fiscalised terms, reflecting a tendency to understand social policy as an adjunct to economic and fiscal policy and related goals (Murphy and Dukelow, 2016). Like in many European countries the welfare state has been downgraded from a golden, to silver, to a bronze age (Arts, 2013). It has been argued that neo-liberalism has been a main driver for change in 
the restructuring of welfare provision and regulation (Dukelow and Murphy, 2016). Privatisation is a key component of neo-liberal policy processes (Hermann, 2007). The transfer of activity through concessions, delegated management contracts, leasing or other forms of public-private partnerships is not always considered as privatisation but can be included as marketisation where non-monetised welfare is commoditised, given a market value and delivered through market mechanisms (Dukelow and Murphy, 2016 p. 20). This can occur thorough the private sector when state functions are outsourced like in the delivery of social housing (Finnerty, O'Connell, and O'Sullivan, 2016) and care (Brennan et al., 2012). In Ireland the forprofit home care sector has quadrupled since 2000, with approximately 150 companies providing home care nationwide ${ }^{1}$. While there is no clear evidence of forprofit designated palliative care services in Ireland (although there are some consultants that hold private and public roles, see Wren, 2002) there is a clear outsourcing of home-care services from the State to for-profit providers and a push for home care for palliative care patients (IHF, 2014; Donnelly et al., 2016).

Palliative care is an important public health issue. It is concerned with the suffering, dignity, care needs and the quality of life of people at the end of their lives. In recent decades we have seen the prioritisation of choice and autonomy as key quality indicators in many western palliative care services (Borgstrom and Walter, 2015; Ho, 2008; IHF, 2014). A clear illustration of this in Ireland and other European countries is the promotion of patient involvement (Dent and Pahor, 2015), especially in relation to place of care and death (Eurobarometer, 2007). In many countries, the delivery of home care has been promoted as the ideal type of formal care, offering cost savings to local authorities and 'choice' for palliative-care patients and their families. In Ireland there is an overlap in the provision of end of life care (EOLC) and palliative care (NCAOP, 2008). While home care is not exclusive to palliative care services, the increasing promotion of home as the ideal place of care and death has made domiciliary care an option among the choices patients can make at the end of life.

While a logic of choice (Mol, 2008) in palliative care has been critiqued in terms of the methodology used (Stajduhar, Allan, Cohen, and Heyland, 2008; Thomas, Morris, and Clark, 2004; Townsend et al., 1990; van der Heide, de Vogel-Voogt, Visser, van der Rijt, and van der Maas, 2007) and the possibility of real choice at the end of life (Borgstrom and Walter, 2015; Drought and Koenig, 2002; Lolich and Lynch, 2016; Lolich and Lynch forthcoming) it is important to examine how the commercialisation of domiciliary palliative care can lead to poor quality of care and exploitative working conditions for employed carers. Ireland is now ranked number 4 worldwide in the overall score in the Quality of Death Index, which takes into account four categories: basic end-of-life healthcare environment; availability of end-of-life care; cost of end-of-life care and quality of end-of-life care (Economist Intelligence Unit, 2015). Therefore, how Ireland is adapting its long history and expertise in palliative care to develop EOLC policies for this newly developing palliative care scenario is of international interest.

1 Primetime, A prime time documentary that aired on Dec 13th 2010 


\section{Deconstructing care: The marketing mix for 'care'}

The marketing mix is a set of controllable marketing tools that a company uses to produce the response it wants from its various target markets and, despite its detractors, it has been widely accepted and used in marketing (Rafiq and Ahmed, 1995; Zeithaml, Bitner, and Gremler, 2009). It consists of everything that a home care agency can do to influence the demand for the services that it offers. Tangible products have traditionally used a 4Ps model (product, price, place and promotion), the service sector on the other hand uses a 7P (Ivy, 2008; Zeithaml, Bitner, and Gremler, 2009) in order to satisfy the needs of the service provider's customers. These are: product, price, place, promotion, people, physical evidence and processes.

By unravelling the specificities of the marketing mix for care, it is possible to detangle 'care' from the positive language of the market (Table 1). The point is not that care cannot be a positive experience but that there is a dark side to the commodification of care that is rarely discussed in the marketing literature. The pursuit of profits, paying for care, contracting and bureaucratising care can reduce care to mundane, physical, measurable elements (Meagher and Cortis, 2009) and might ignore the emotional and relational aspects of care which cannot easily be costed or detailed in contracts. The commodification of care can be detrimental to the quality of life of the two parties involved in the market exchange: the vulnerable people in end of life care (EOLC) and the vulnerable workers - women, often poor and/or migrant.

Table 1: The extended marketing mix for domiciliary care

\begin{tabular}{|l|l|l|}
\hline \multirow{3}{*}{ Product } & Definition & $\begin{array}{l}\text { Consequences of the } \\
\text { commodification of domiciliary } \\
\text { care }\end{array}$ \\
\hline $\begin{array}{l}\text { The product is what is being sold. } \\
\text { In the case of home care it is a } \\
\text { complex bundle of activities, } \\
\text { tasks and interactions that aim to } \\
\text { satisfy the patient's care needs. }\end{array}$ & $\begin{array}{l}\text { Defined as physical act e.g. } \\
\text { bathing, toileting and dressing. } \\
\text { Quantifiable and measurable set of } \\
\text { activities. No time allocated for } \\
\text { compassion or companionship. }\end{array}$ \\
\hline $\begin{array}{l}\text { The price element of the services } \\
\text { marketing mix is what is being } \\
\text { charged for a care package. }\end{array}$ & $\begin{array}{l}\text { Price needs to be higher than cost. } \\
\text { Cost can be reduced by increasing } \\
\text { productivity (higher patients to staff } \\
\text { ratio) which results in lower quality } \\
\text { of care. Profits can also be } \\
\text { increased by reducing cost of staff. }\end{array}$ \\
\hline Place & $\begin{array}{l}\text { Place is the distribution method } \\
\text { that the agency adopts to provide } \\
\text { care to its market. }\end{array}$ & $\begin{array}{l}\text { Prioritisation of home as the ideal } \\
\text { place of care. Little control over the } \\
\text { work space. }\end{array}$ \\
\hline Promotion & $\begin{array}{l}\text { Promotion encompasses all the } \\
\text { tools that home care providers } \\
\text { can use to provide the market } \\
\text { with information on its offerings. }\end{array}$ & $\begin{array}{l}\text { Language of the market contains } \\
\text { only positive terms; however, care } \\
\text { labour is physically and } \\
\text { emotionally demanding work. }\end{array}$ \\
\hline
\end{tabular}




\begin{tabular}{|l|l|l|}
\hline People & $\begin{array}{l}\text { The people element of the } \\
\text { marketing mix includes all the } \\
\text { staff of the home care agency } \\
\text { that interacts with prospective } \\
\text { and current patients. }\end{array}$ & $\begin{array}{l}\text { Care work is disproportionally } \\
\text { women's work and increasingly } \\
\text { racialised. }\end{array}$ \\
\hline $\begin{array}{l}\text { Physical } \\
\text { evidence }\end{array}$ & $\begin{array}{l}\text { Physical evidence is the tangible } \\
\text { component of the service } \\
\text { offering. The quality of care is } \\
\text { hard to assess and monitor. }\end{array}$ & $\begin{array}{l}\text { Market provision, driven by } \\
\text { efficiency, will tend to meet the } \\
\text { measurable outputs and side-line } \\
\text { the less tangible aspects of good } \\
\text { care }\end{array}$ \\
\hline Process & $\begin{array}{l}\text { Processes are all the } \\
\text { administrative and bureaucratic } \\
\text { functions of home care providers: } \\
\text { from the handling of enquiries to } \\
\text { registration, from making rotas } \\
\text { and time parameters to defining } \\
\text { work tasks, to name but a few. }\end{array}$ & $\begin{array}{l}\text { Formal process of caring tightly } \\
\text { controlled while the informal } \\
\text { aspects of it, the emotional work } \\
\text { involvare side-lined. }\end{array}$ \\
\hline
\end{tabular}

\section{The product element: care as a commodity}

The product is what is being sold. In the case of home care it is a complex bundle of activities, tasks and interactions that aim to satisfy the patient's care needs. Multiple meanings of care have developed over the past decades, particularly within feminist writing, with distinctions drawn between caring about and caring for, between care as work and care as emotion and care as practice and care as disposition (Lloyd, 2012). In the commercialised home care market, the services the agency contracts to deliver to service users are defined as physical acts, 'work tasks', such as bathing or showering, washing and dressing, toileting and incontinence (PA Consulting and IPHCA, 2009 p.35). Care as a product is tightly defined as a quantifiable and measurable set of activities.

Care becomes an abstract noun, a package to be delivered to service users, the manner in which care acts are undertaken is not accounted for (Borgstrom and Walter, 2015). Allowing a patient a few minutes of time and attention to express fear, share a thought, or tell a story is excluded from the formulary of productive activities and as such is a 'non-productive activity' subject to administration sanction (Diamond, 1995). In a study done in Ireland (Timonen and Doyle, 2007) home care staff complained that there was no time allocated for companionship or compassion. Care is now a tradable commodity and domiciliary carers have to continually reconcile the tensions inherent in a care plan that offers no time to care (Bolton and Wibberley, 2014).

Quality differences are inherent in market provision; indeed it is through such differences that markets are supposed to promote efficiency (Brennan et al., 2012). First, for quality control to work in care markets consumers must be able to switch poor quality providers for higher quality ones (Brennan et al., 2012). However, continuity of care is important for people in care, so that exit can be too costly a 
strategy (in emotional and time terms) when quality is found to be inferior. Carers learn how to care for particular people (Waerness, 1987). This tacit knowledge takes time to acquire and cannot instantly be replaced by a carer offering better value for money (Land and Himmelweit, 2010).

Second, making use of market information requires skills that are not equally distributed; an increased focus on choice favours those with more resources and education, who have considerable advantages in navigating the system (Eika, 2006). Third, where the market provides for both privately and publicly funded care, or care recipients are expected to top-up the service provided through their own resources, those with greater resources will be able to purchase higher quality. This critically limits the effectiveness of market mechanisms in ensuring care quality (Eika, 2009; Plantenga, 2010).

In recognition of these problems, governments may seek to aid transparency and effective choice through regulation, accreditation and the provision of information about how individual services perform against the standards. Inevitably, such standards capture the most easily quantifiable aspects of care rather than the less tangible, relational features that are of such importance to care recipients and their families (Waerness, 1987). Despite the US nursing home industry being one of the most highly regulated worldwide, this has not necessarily increased the quality of care for its patients (Harrington, 2001). Regulation has become a form of 'ritualism' where the providers go along with institutionalised means for achieving regulatory goals while not actually attaining the goals themselves (Braithwaite, 1993). The result is the bureaucratization of care provision and an overemphasis on tangible care aspects that are irrelevant to or a hindrance to individual care. An overemphasis on tangible and measurable aspects may also undermine the motivation of care workers; formal requirements that are perceived as problematic may crowd out workers' genuine motivation for good care (Frey, 1992).

\section{The price element: cost and value in care}

The price element of the services marketing mix is what is being charged for a care package. The pricing element is important in terms of bringing revenue to the agency and also as a criterion in the decision-making process for patients. In order for the business to be sustainable and make a profit, price has to be higher than costs. Providers in the for-profit sector fail in their duty to shareholders if they do not take every opportunity to reduce cost and increase profits. One way that profits can be increased is by increasing productivity, however it is hard to lower costs and increase productivity of care, because the need to develop a relationship with clients sets a limit on how many people can be cared for at the same time or how many home-care visits can be made in a day, without reducing the quality of care provided (Land and Himmelweit, 2010). Spreading care over more people becomes synonymous with reducing quality. This is not caused by the inefficiency in care provision but is inherent in the relational nature of care.

Another way to increase profits is by trying to reduce the cost of staff. The IPHCA claimed in 2009 that: 'Higher staff costs are the primary factor driving higher cost in the public and non-profit sectors [in the home care market] (PA Consulting and IPHCA 2009, p. 1). The low wages in the care sector causes recruitment and 
retention problems (Land and Himmelweit, 2010) and this directly affects the quality of care that can be provided. For care to be of good quality, the care workforce needs to be paid wages comparable with those in other occupations.

In the absence of other information on the quality of the care provided, price becomes an important criterion to make a purchase decision. This applies not only for the end consumer, but also when for-profit agencies compete with one another and against public and non-profit providers for government contracts to deliver care packages to people at home. In the past few years the for-profit-led group, Home and Community Care Ireland $(\mathrm{HCCl})$, has been lobbying the government for an outsourcing of home care service provision in Ireland ( $\mathrm{HCCl} 2013$, p. 4) claiming savings of up to $€ 2$ billion by transferring the home care provision to the private sector. In a report submitted to the Irish government, the IPHCA (2009, p. 2) stated: 'the current context of pressure to realise savings whilst meeting rising demand for home care highlights the need for the approach to the market to be reconsidered". Since September 2016 all new Home Care Packages approved by the Health Services Executive (HSE) are provided by organisations that have been selected following a tender process. Currently, there are 32 approved providers and this includes private providers (HSE, 2016). In the absence of reliable information about quality, price competition can lead to pursuit of 'value for money' that becomes a race to the bottom in terms of quality (Land and Himmelweit, 2010).

Studies of care service industries that indicated less efficiency in non-profits than in for-profits might not take into account the possibility that non-profits are supplying different kinds or qualities of services (Clarkson and Martin, 1980). In Ireland, it was found that a public nursing home bed costs more than in the private sector, however, as the HSE pointed out this is due to higher nurse staffing ratios, better terms and conditions for staff, the types of building used and geographical locations of services (Wall, 2016). Timonen and Doyle's (2007) study of domiciliary care in Ireland found that the composition of the care workforce is more diverse in the for-profit than in the public and non-profit sector operations, and in the nature of the tasks expected. Furthermore, the lack of regulation of the for-profit and non-profit (voluntary) domiciliary care sectors also facilities more flexibility with regard to qualifications, training and monitoring (Timonen and Doyle 2007, p.261) which allows managers to reduce standards in terms of hiring staff, training and paying them.

\section{The place element: home as a place of care}

Place is the distribution method that the agency adopts to provide care to its market. Place is an important element in services competition, especially in public services as many users want to receive services close to their home (Rankin, 2005), not least, because they might require it regularly or they may actually require the service at home, as is the case with domiciliary palliative care.

The prioritisation of home as the ideal place of care and death has grown significantly in Ireland and many other countries (Borgstrom and Walter, 2015; IHF, 2014; McKeown et al., 2015; Weafer and Associates, 2004). In the UK, the NHS and Community Care Act 1990, emphasised as their objective a reduction in residential care for older people and an increase in the provision of home care (Bolton and 
Wibberley, 2014) and in Ireland, the Irish Hospice Foundation (2014) proposed home as a place of care and death as a key quality indicator for palliative care.

A major factor shaping the domiciliary carer's labour process is that it takes place within a client's own home, where ability to control workspace is limited. Clients' homes can be challenging as a workplace as they vary in their layout, cleanliness, atmosphere, inhabitants, equipment and space (Bolton and Wibberley, 2014 p.688). Working in a range of different work spaces throughout the day means that domiciliary carers must continually be on the move between clients' homes, resulting in the introduction of ever more complex control mechanisms to ensure efficiency levels are maintained. Often domiciliary carers are scheduled to arrive at the next client at the same time as leaving their previous client; a logistical nightmare for managers, domiciliary carers, and clients (Bolton and Wibberley, 2014).

\section{The promotion element: promoting choice}

Promotion encompasses all the tools that home care providers can use to provide the market with information on its offerings: advertising, public relations, sponsorship, direct marketing and sales promotional efforts. Different promotional tools are used for different publics. For example lobbying (public relations) is used to influence government policy and mass media, like radio and $\mathrm{TV}$, are used to communicate with prospective or current clients. When promoting home care as a product to be bought, a logic of care is replaced with a logic and language of the market (Mol, 2008). The language of market contains only positive terms. Products for sale are attractive. Tellingly and non-neutrally, they are called goods (Mol, 2008). Classifying patients as consumers creating value raises concerns (Nordgren, 2008). Patients accessing home care services become customers in 'careland' (Mol, 2008 p.32) and like other customers, they are invited to enter the market to buy care packages that they find attractive. However, the customer in domiciliary palliative care is a vulnerable customer and therefore a service provider's actions could be to the detriment of the customer (Hardyman, Daunt, and Kitchener, 2015 p. 101). The same frailty and dependence that creates the need for care limits 'consumer sovereignty' (Eika, 2009; Lolich and Lynch forthcoming).

For providers of care it is difficult to communicate the intangible aspects of good care when promoting their services. At the same time, it is equally difficult for patients and their relatives to gauge the quality of home care services before its purchase. Therefore, agencies may end up promoting, and patients may end up making choices, based not on quality of care (Greener, 2008), but on elements that are not intrinsic to care, for example price and locality. In this case, a choice of sorts is possible, but the focusing on elements that are peripheral to care is surely the basis for a rather irrational market, and one that creates particularly perverse incentives for health managers overseeing the delivery of the care services (Greener, 2008). In such a market it would make sense, for example, to spend money on branding and save on staff training. When patients are asked to choose in situations where the decision process is far from clear, marketing can provide a number of techniques for 'framing' (Callon, 1998; Callon, Méadel, and Rabeharisoa, 2002) the decision before choosers, which might or might not be in the best interest of all parties involved. Where services are of a type where users may not be able to accurately assess them, significant efforts might be made to attempt to differentiate services on the 
basis of elements that make little or no difference to the quality of care on offer (Greener, 2008), for example, price.

\section{The process element: formal and informal labour process}

Processes are all the administrative and bureaucratic functions of home care providers: from the handling of enquiries to registration, from making rotas and time parameters to defining work tasks, to name but a few. Bolton and Wibberley (2014) delineate domiciliary care across two axes; the formal and informal labour process.

The formal process is tightly controlled with rotas defining the time parameters and intensifying the work; care plans specify a clear agenda via a task-based approach to care. On the other hand, the informal process includes tasks that are necessary but are not acknowledged in the care plan, such as information provision (Cooper and Urquhart, 2004) and the continual emotional work involved in delivering caring tasks (Brown and Korczynski, 2010; Stacey, 2011). Home-care organisations (and clients) become reliant on the discretionary effort of domiciliary carers (informal labour process) for good domiciliary care to be delivered. Structurally, the problem with domiciliary care and other care occupations is that it is difficult to increase profitability through any other means than standardising and intensifying the pace of work for the care givers (Bolton and Wibberley, 2014). Caring motivation - a guarantee of quality and effectiveness - can be squeezed out, with the risk that care is performed impersonally and to minimum standards (Folbre and Nelson, 2000; King and Martin, 2009).

\section{The people element: people in care}

The people element of the marketing mix includes all the staff of the home care agency that interacts with prospective and current patients. This article focuses on the most vulnerable group, the carer. Care work is disproportionately women's work, especially where it involves hands-on caring, paid or unpaid (Bolton, 2009; Bolton and Wibberley, 2014). This is the case not only in private markets but also in the public sector and the private sphere. Women are morally impelled by family members and by welfare authorities to take care responsibilities and provide care support to others throughout most countries (Isaksen, 2002; Kawachi and Berkman, 2001). In Ireland, the home care market is staffed $95-100 \%$ by women (Timonen and Doyle, 2007).

Care work is not only gendered it is also classed and increasingly racialised (Gutierrez-Rodriguez, 2014; Parreñas, 2001). Migrant workers in Ireland are at high risk of exploitation, discrimination and face precarious working conditions and chronic underpayment (MRCI, 2015). The for-profit home care sector in Ireland has a higher percentage of non-Irish workers than the public sector (Timonen and Doyle, 2007). The privatisation of home care services has worsened conditions of employment, making care jobs unattractive (McGregor, 2007). Since care markets deliver efficiency at the expense of workers' pay and conditions, care workers tend to be drawn from vulnerable groups in society: traditionally women and increasingly in eldercare, migrants (Shutes and Chiatti, 2012). 


\section{The physical evidence element: judging quality in care}

Physical evidence is the tangible component of the service offering. The quality of care is hard to assess and monitor. Care is a quintessentially 'soft' product whose essential characteristics are not easily measured. It is possible to monitor the attainment of certain physical tasks, such as, whether a client has been bathed or taken their medicine. Market-driven provision, its drive for efficiency, will tend to meet these measurable outputs and economise on the less tangible aspects of good care (Land and Himmelweit, 2010).

When buyers have trouble evaluating the quality characteristics of the commodity, the market operates under conditions of asymmetric information; that is, buyers are at a disadvantage in exchange vis-à-vis sellers who have more information. If the patient cannot communicate his or her care experience to their representatives and these are not present when the care occurs, then conceptualising care as a commodity might reveal the person receiving care as an object to be produced. The quality of the care might be solely judged on the transformation of soiled, hungry, anxious people into clean, replete, calm people (Lee-Treweek, 1997; Toynbee, 2007; Wolkowitz, 2002). For-profit firms selling to poorly informed customers have an incentive to engage in hidden action; that is, to provide inferior quality on those aspects of services customers cannot evaluate (Morris and Helburn, 2000; Walker, 1991).

\section{Conclusion}

The home care industry has grown exponentially around the world. Within palliative care, the delivery of home care has been promoted as the ideal type of formal care; offering cost savings to local authorities and 'choice' for patients and their families. However, there is a dark side to the commodification of home care that is rarely discussed in the marketing literature. The paper critically examined the marketing mix for the care product, highlighting issues of inequality for patients and carers.

The commodification of care obscures the tensions between providing good quality care and making a profit. It also obscures the affective inequalities for patients and care providers. In the discourses of the market we do not see any suffering or vulnerability. One of the problems associated with importing choice into palliative care services can be explained by the fact that a logic of choice emanates from an economic system of thought which differs from a logic of care (Mol, 2008). Patients in home care are normally vulnerable people who are 'buying' into a service that they desperately need but not necessarily want. On the other hand, carers are doing a job that they might enjoy to an extent but that they would not necessarily choose. When these vulnerable groups meet under market conditions there is a tension between 'care' and 'profit'. Health care policies seem to have not considered the simplistic nature of the language of choice, when using it for home care services. The logic of the market excludes patient's vulnerability, lack of knowledge, the asymmetric relationship, the dependency and the need for care, as well as his or her varying abilities to make choices (Nordrgren 2010). It fails to take account of prior inequalities in power relations, economic and affective resources and differences in cultural values (Lolich and Lynch, forthcoming). The logic of the market also seems 
to have overestimated patients' willingness to opt for choice in end of life care and carers' possibility to provide good care under market conditions.

The article underscores the importance of understanding the limitations of care markets and in doing so has highlighted that further work concerning the application of marketing strategies to domiciliary care is warranted. Determining how people can be properly cared for in a way that exploits no caregivers in particular, is the most profound challenge that remains in our society.

\section{Acknowledgments}

This work was supported by the Health Research Board (HRB) and the All Ireland Institute of Hospice and Palliative Care (AIIHPC).

\section{References}

Arts, W. (2013) 'Welfare regimes in an age of austerity', Sociologia e Politiche Sociali, 16(1), pp. 9-23.

Bolton, S. (2009) 'The lady vanishes: women's work and affective labour', International Journal of Work Organisation and Emotion, 3(1), pp. 72-80.

Bolton, S., and Wibberley, G. (2014) 'Domiciliary care: the formal and informal labour process', Sociology, 48(4), pp. 682-697.

Borgstrom, E., and Walter, T. (2015) 'Choice and compassion at the end of life: a critical analysis of recent English policy discourse', Social Science and Medicine, 136-137, pp. 95105.

Braithwaite, J. (1993) 'The nursing home industry', in Tonry, M. and Reiss, J. (eds.), Crime and justice: beyond the law: crime in complex organizations volume 18: annual review of research. Chicago: University of Chicago Press.

Brennan, D., Cass, B., Himmelweit, S., and Szebehely, M. (2012) 'The marketisation of care: rationales and consequences in Nordic and liberal care regimes', Journal of European Social Policy, 22(4), pp. 377-391.

Brown, K. and Korczynski, M. (2010) 'When caring and surveillance technology meet: organizational commitment and discretionary effort in home care work', Work and Occupations, 37(3), pp. 404-432.

Callon, M. (1998). 'Introduction: the embeddedness of economic markets in economies', in Callon, M. (ed.), The laws of the markets. Oxford: Blackwell, pp. 1-57.

Callon, M., Méadel, C. and Rabeharisoa, V. (2002) 'The economy of qualities', Economy and Society, 31(2), pp. 194-217.

Clarkson, K., and Martin, D. (1980) The economics of nonproprietary organizations. Greenwich, CT: JAI Press.

Cooper, J. and Urquhart, C. (2005) 'The information needs and information-seeking behaviours of home-care workers and clients receiving home care', Health Information and Libraries Journal, 22(2), pp. 107-116. 
Dent, M., and Pahor, M. (2015) 'Patient involvement in Europe - a comparative framework', Journal of Health Organization and Management, 29, pp. 546-555.

Diamond, T. (1995) Making gray gold: narratives of nursing home care. Chicago: University of Chicago Press.

Donnelly, S., O'Brien, M., Begley, E. and Brennan, J. (2016) 'I'd prefer to stay at home but I don't have a choice': meeting older people's preference for care: policy, but what about practice? Research Repository UCD [Online]. Available at: http://hdl.handle.net/10197/7670 (Accessed: 5 March 2017).

Drought, T., and Koenig, B. (2002). '"Choice" in end-of-life decision making: researching fact or fiction?' The Gerontologist, 42(3), pp. 114-128.

Dukelow, F., and Murphy, M. P. (2016) 'Welfare states: how they change and why', in Murphy, M. and Dukelow, F. (eds.) Irish welfare state in the twenty-first century: challenges and change. London: Palgrave Macmillan, pp. 13-35.

Economist Intelligence Unit (2015) 'The 2015 quality of death index: ranking palliative care across the world. Available at: https://www.eiuperspectives.economist.com/sites/default/files/2015\%20EIU\%20Quality\%200 f\%20Death\%20Index\%200ct\%2029\%20FINAL.pdf (Accessed: 3 March 2017).

Eika, K. (2010) 'Consumers of human services: powerless or poorly informed?', Nordic Journal of Political Economy, 36. Available at:

http://www.nopecjournal.org/NOPEC 2010 a02.pdf (Accessed: 16 March 2017).

Eika, K. (2009) 'The challenge of obtaining quality care: limited consumer sovereignty in human services', Feminist Economics, 15(1), pp. 113-137.

Eurobarometer (2007) Health and long-term care in the European Union. Available at: http://ec.europa.eu/public opinion/archives/ebs/ebs 283 en.pdf (Accessed: 13 March 2017).

Eurostat (2017) Europe in figures: Eurostat yearbook 2015. Luxembourg: Publications Office of the European Union.

Finnerty, J., O'Connell, C. and O'Sullivan, S. (2016) 'Social housing policy and provision: a changing regime?', in Murphy, M. and Dukelow, F. (eds.) The Irish welfare state in the twenty-first century: challenges and change. London: Palgrave Macmillan, pp. 237-260.

Folbre, N., and Nelson, J. (2000) 'For love or money: or both?', Journal of economic perspectives, 14(4), pp.123-140.

Frey, B. (1992) 'Tertium datur: pricing, regulating and intrinsic motivation', Kylos, 45, pp.161184. Available at:

http://search.ebscohost.com/login.aspx?direct=true\&AuthType=ip,shib,cookie,url\&db=bah\&A

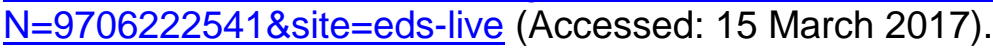

Greener, I. (2008) 'Markets in the public sector: when do they work, and what do we do when they don't?', Policy and Politics, 36(1), pp. 93-108.

Greener, I. (2005) 'The role of the patient in healthcare reform: customer, consumer or creator?', in Dawson, S. and Sausman, C. (eds.) Future health organisations and systems. Basingstoke: Palgrave, pp. 227-245.

Gutierrez-Rodriguez, E. (2014) 'Domestic work-affective labor: on feminization and the coloniality of labor', Women's Studies International Forum, 46(1), pp. 45-53. 
Hardyman, W., Daunt, K., and Kitchener, M. (2015) 'Value co-creation through patient engagement in health care: a micro-level approach and research agenda', Public Management Review, 17(1), pp. 90-107.

Harrington, C. (2001) 'Regulating nursing homes: residential nursing facilities in the United States', British Medical Journal, 323(7311), pp. 507-510.

Health Service Executive (2016) Home Care Packages. Available at: http://www.hse.ie/eng/services/list/4/olderpeople/homecarepackages/ (Accessed: 12 March 2017).

Hermann, C. (2007) 'Neoliberalism in the European Union', Studies in Political Economy, 79(1), pp. 61-89.

Ho, A. (2008) 'Relational autonomy or undue pressure? Family's role in medical decisionmaking', Scandinavian Journal of Caring Sciences, 22(1), pp. 128-135.

Home and Community Care Ireland (2013) 'The business case for outsourcing of home care provision and a more efficient use of Fair Deal funds'. Available at:

https://www.oireachtas.ie/parliament/media/committees/jobsenterpriseandinnovation/ $\mathrm{HCCl}-$ Report.pdf (Accessed: 23 February 2017).

Irish Hospice Foundation (2016) Supporting people with dementia to die at home in Ireland. Available at:

http://hospicefoundation.ie/wp-content/uploads/2016/07/IHF-Brief-Report-Supporting-peoplewith-dementia-to-die-at-home-2-1.pdf (Accessed: 5 March 2017).

Irish Hospice Foundation (2014) Enabling more people to die at home: making the case for quality indicators as drivers for change on place of care and place of death in Ireland.

Available at:

http://hospicefoundation.ie/wp-content/uploads/2014/12/Enabling-More-People-to-Die-atHome1.pdf (Accessed: 8 March 2017).

Isaksen, L. W. (2002) 'Toward a sociology of (gendered) disgust: images of bodily decay and the social organization of care work', Journal of Family Issues, 23(7), pp. 791-811.

Ivy, J. (2008) 'A new higher education marketing mix: the 7Ps for MBA marketing', International Journal of Educational Management, 22(4), pp. 288-299.

Kawachi, I., and Berkman, L. F. (2001) 'Social ties and mental health', Journal of Urban Health, 78(3), pp. 458-467.

King, D., and Martin, B. (2009) 'Caring for profit? The impact of for-profit providers on the quality of employment in paid care', in Meagher, G. and King, D. (eds.) Paid care in Australia: politics, profits, practices. Sydney: Sydney University Press, pp. 227-245.

Land, H., and Himmelweit, S. (2010) 'Who cares: who pays? A report on personalisation in social care', London: Unison. Available at:

http://oro.open.ac.uk/26419/ (Accessed: 20 February 2017).

Lee-Treweek, G. (1997) 'Women, resistance and care: an ethnographic study of nursing auxiliary work', Work, Employment and Society, 11(1), pp. 47-63.

Lloyd, L. (2012) Health and care in ageing societies: a new international approach. Bristol: Policy Press.

Lolich, L. and Lynch, K. (2016) 'Control and care at the end of life: performing the 'good death' in palliative care, an Irish perspective', Irish Journal of Anthropology, Vol.19 (1) pp. 100-108. 
Lolich, L., and Lynch, K. (forthcoming) No choice without care: problematizing choice at the end of life, an Irish perspective.

Markets and Markets (2015) Home healthcare - global forecasts to 2020. Available at: http://www.marketsandmarkets.com/Market-Reports/home-healthcare-equipment-market696.html (Accessed: 21 February 2017).

McGregor, J. (2007) 'Joining the BBC (British Bottom Cleaners): Zimbabwean Migrants and the UK Care Industry', Journal of Ethnic and Migration Studies, 33(5), pp. 801-824.

McKeown, K., Haase, T., Pratschke, J., Twomey, S., Donovan, H. and Engling, F. (2015) 'Determinants of care outcomes for patients who die in hospital in Ireland: a retrospective study', BMC Palliative Care, 14(11), pp. 1-8.

Meagher, G., and Cortis, N. (2009) 'The political economy of for-profit paid care: theory and evidence', in King, D. and Meagher, G. (eds.) Paid care in Australia: politics, profits, practices. (Sydney: Sydney University Press, pp. 13-36.

Migrants Rights Centre Ireland (2015) 'All work and low pay: the experience of migrants working in Ireland'. Available at:

http://www.mrci.ie/wp-content/uploads/2015/11/MRCl-All-Work-and-Low-Pay.pdf (Accessed: 12 February 2017).

Mol, A. (2008) The logic of care: health and the problem of patient choice. London: New York: Routledge.

Morris, J., and Helburn, S. (2000) 'Child care center quality differences: the role of profit status, client preferences, and trust', Nonprofit and Voluntary Sector Quarterly, 29(3), pp. 377-399.

Murphy, M. P., and Dukelow, F. (2016) 'Introduction', in Murphy, M. and Dukelow, F. (eds.) The Irish welfare state in the twenty-first century: challenges and change. London: Palgrave Macmillan, pp. 1-12.

National Council on Ageing and Older People (2008) End-of-life care for older people in acute and long-stay care settings in Ireland. Available at:

http://www.ncaop.ie/publications/research/reports/103 EOL Care Report.pdf (Accessed: 15 March 2017).

Nordgren, L. (2008) 'The performativity of the service management discourse: "value creating customers" in health care', Journal of Health Organisation and Management, 22(5), pp. 510-528.

PA Consulting and IPHCA. (2009) 'Analysis of Irish home care market'. Available at: http://bluebirdcare.ie/IPHCAHomeCareMarketReport.pdf (Accessed: 13 March 2017)

Parreñas, R. S. (2001) Servants of globalization: women, migration and domestic work. Stanford, CA: Stanford University Press.

Plantenga, J. (2010) 'Local providers and loyal parents. Competition and consumer choice in the Dutch childcare sector', Paper presented at the Social Policy Association Conference, Lincoln University, 5-7 July 2010.

Rafiq, M., and Ahmed, P. (1995) 'Using the 7Ps as a generic marketing mix: an exploratory survey of UK and European marketing academics', Marketing Intelligence \& Planning, 13(9), pp. 4-15.

Rankin, J. (2005) 'Choice matters: the NHS could learn a lot from social care', The Guardian, 21 September [Online]. Available at: 
https://www.theguardian.com/society/2005/sep/21/publicservices.publicservices (Accessed: 20 March 2017).

Schedler, K., and Proeller, I. (2002) 'New public management: current trends and future prospects', in McLaughlin, K., Osborne, S. and Ferlie, E. (eds.) New public management: current trends and future prospects. London; New York: Routledge, pp. 163-180.

Shutes, I., and Chiatti, C. (2012) 'Migrant labour and the marketisation of care for older people: the employment of migrant care workers by families and service providers', Journal of European Social Policy, 22(4), pp. 392-405.

Stacey, C. (2011) The caring self: the work experiences of home care aides. Ithaca, NY: ILR Press.

Stajduhar, K. I., Allan, D. E., Cohen, S. R., and Heyland, D. K. (2008) 'Preferences for location of death of seriously ill hospitalized patients: perspectives from Canadian patients and their family caregivers', Palliative medicine, 22(1), pp. 85-88.

Tarricone, R. and Tsouros, A. (eds.) (2008) The solid facts: home care in Europe Copenhagen: World Health Organization.

Taylor-Gooby, P., Larsen, T., and Kananen, J. (2004) 'Market means and welfare ends: The UK welfare state experiment', Journal of Social Policy, 33(4), pp. 573-592.

Thomas, C., Morris, S. M., and Clark, D. (2004) 'Place of death: preferences among cancer patients and their carers', Social science and medicine, 58(12), pp. 2431-2444.

Timonen, V., and Doyle, M. (2007) 'Worlds apart? Public, private and non-profit sector providers of domiciliary care for older persons in Ireland', Journal of Aging Studies, 21(3), pp. 255-265.

Townsend, J., Frank, A. O., Fermont, D., Dyer, S., Karran, O., Walgrove, A., and Piper, M. (1990) 'Terminal cancer care and patients' preference for place of death: a prospective study', British Medical Journal (Clinical research ed.), 301(6749), pp. 415-417.

Toynbee, P. (2007) 'Rethinking humanity in care work', in Bolton, S. and Houlihan, M. (eds.) Searching for the human in human resource management : theory, practice and workplace contexts. Basingstoke: Palgrave Macmillan, pp. 219-243.

van der Heide, A., de Vogel-Voogt, E., Visser, A. P., van der Rijt, C. C. D., and van der Maas, P. J. (2007) 'Dying at home or in an institution: perspectives of Dutch physicians and bereaved relatives', Supportive Care in Cancer, 15(12), pp.1413-1421.

Waerness, K. (1987) 'On the rationality of caring', in Sassoon, A.S. (ed.) Women and the state: the shifting boundaries of public and private. London: Hutchinson, pp. 207-234.

Walker, J. R. (1991) 'Public policy and the supply of child care services', in Blau, D. (ed.) The economics of child care. New York: Russell Sage Foundation.

Wall, M. (2016) 'Public nursing home bed costs $€ 700$ more than private sector', The Irish Times, 5 October [Online]. Available at:

http://www.irishtimes.com/news/ireland/irish-news/public-nursing-home-bed-costs-700-morethan-private-sector-1.2816765. (Accessed: 20 March 2017).

Weafer and Associates (2004) 'A nationwide survey of public attitudes and experiences regarding death and dying'. Available at:

http://hospicefoundation.ie/wp-content/uploads/2012/04/Weafer-et-al-2004-A-nationwidesurvey-of-public-attitudes-and-experiences-regarding-death-and-dying.pdf. (Accessed: 20 March 2017). 
Luciana Lolich

Wolkowitz, C. (2002) 'The social relations of body work', Work, Employment and Society, 16(3), pp. 497-510.

Wren, M.-A. (2002) Unhealthy state: anatomy of a sick society. Dublin: New Island.

Zeithaml, V., Bitner, M., and Gremler, D. (2009) Services marketing: integrating customer focus across the firm. Boston: McGraw-Hill Irwin. 